\title{
ASSESSMENT OF BUSINESS EFFICIENCY OF AGRICULTURAL HOLDINGS WITH DIFFERENT PRODUCTIONS ${ }^{1}$
}

\author{
Dragan Orović, Ivana Ljubanović Ralevic ${ }^{3}$, Ana Anokić ${ }^{4}$
}

\begin{abstract}
Summary
The subject of this paper is the use of DEA methodology for the evaluation and analysis of the total technical efficiency (TE) which also includes the pure technical efficiency (PTE) and scale efficiency (SE). The operations of three groups of 20 individual farms, with different primary production, field crops, fruit and livestock, are analysed in the present paper. The necessary data for the development of the basic model have been collected by the survey conducted on 60 agricultural households on the territory of Toplice region. Surveyed households have 92 tractors, 108 different ploughs, 63 sprayers and other necessary mechanization. In addition, 677.7 ha of agricultural land, which is located at 1,201 plots, are cultivated by surveyed households. These farms keep 291 cows, 118 bulls, 366 pigs, 459 sheep and others. 91 workers and farm members are engaged in operation of the farms. The aim of the paper is to determine whether there is a difference in the technical efficiency of different types of households.
\end{abstract}

Key words: DEA methodology, technical efficiency, scale efficiency, family farms, primary production.

JEL: $Q 12, M 24$

\section{Introduction}

The evaluation of efficiency of various types of business organizations is of great importance. The idea of defining the limits of efficiency was proposed by (Farrell, 1957), who described two types of economic efficiency: technical efficiency (TE) and allocative

1 Paper is a part of research within the project for technological development no TR 31051 financed by the Ministry of Education, Science and Technological Development of the Republic of Serbia.

2 Dragan Orović, M.Sc., lecturer, College of Agriculture and Food Technology, Ćirila i Metodija Street no. 1, 18400 Prokuplje, Serbia, Phone: +381 27324 311, E-mail draganorovic@gmail.com

3 IvanaLjubanović Ralević, Ph.D., Full Professor, University of Belgrade, Faculty of Agriculture, Nemanjina Street no. 6, 11080 Zemun, Serbia, Phone: +381 1126 15 315/int 409, E-mail iralevic@agrif.bg.ac.rs

4 Ana Anokić, B.Sc, Assistant, University of Belgrade, Faculty of Agriculture, Nemanjina Street no. 6, 11080 Zemun, Serbia, Phone: +381 112615 315/int 419, E-mail anokicana@agrif.bg.ac.rs 
efficiency (AE) or price efficiency. Various methods have been used for calculating or evaluating the efficiency limits, since then. They can be classified into two groups: parametric, which are based on econometric evaluation of the production function and nonparametric, which are based on the technique of mathematical programming. Nonparametric models, of which the DEA (Data Envelopment Analysis) methodology is the best known, are widely used for the efficiency assessing. Its advantage compared to parametric methods lies in the fact that it is not based on assumptions about the functional relation between input and output, as is the case in the regression analysis, but it deals with the analysis of the efficiency limits. In addition to the determination of the technical efficiency and the analysis of changes in inputs/outputs, the rank of the organizations, the calculation of the index for changing efficiency coefficients and other are used for improvement of this method. It is common that the investigated organization or unit is identified as DMU (Decision Making Unit) or decision unit. The improvement of the technical efficiency enables the observed DMU to realize higher output with the available input.

There are a number of studies that have applied DEA methodology in agriculture. Agricultural production is characterized by the input factors that are fixed or quasi-fixed, and very slow to adapt. Such factors include the lease of land for a longer period, the share of labour in the production and similar. The existence of such production factors can influence the technical inefficiency and encourage their correction through agricultural policy. Based on Farrell's efficiency measure this correction refers to the proportional reduction of all factors involved in production. Due to the specific structure of agricultural production that proportional reduction of all inputs will have no effect on the proportional reduction of outputs.

The majority of papers, studies are related to the analysis of the efficiency of various forms of farm production in different organizations. For the analysis and decomposition of the overall efficiency of sheep farms in Greece, Fousekis and associates (2001) have used data for 101 farms of the three mountainous regions, based on data for 1997 from the FADN base. Production technology was characterized by two outputs (meat and milk) and five inputs (labour, capital, cost of forage, produced fodder and herd size), which were analysed using input-oriented CRS and VRS DEA model. In the study of (Galanopoulos et al., 2006), the technical and scale efficiency of commercial pig farms in Greece are analysed. The study used 100 of a total of 358 commercial pig farms in several areas, classified into three groups according to the number of sows. DEA methodology is used (Haji, 2007) for evaluation of the technical, allocative and economic efficiency in small mixed farms with crop production in eastern Ethiopia. This study indicates that income, household size, counselling services and the number of household members significantly affect the technical efficiency. Hansson and Öhlmér (2008) have investigated how managerial practices relating to health, breeding and animal nutrition can affect the efficiency of the farm. In the paper of Bojnec and Latruffe (2009) the technical efficiency of Slovenian farms is analysed during the ten-year period (1994-2003) of the transition to a market economy, before joining the European Union. In this paper, the output-oriented model with single output (total revenue) and four inputs (land used, annual work units, the value of total assets in equity and the 
value of the variable input) is used. Artukoglu and associates (2010) have analysed the efficiency of 62 farms with organic and 62 farms with conventional production of olives. The CRS and VRS input and output-oriented models were used for the analysis of six inputs (land (ha), the cost of fertilizer (YTL), organic controls for pests and diseases (YTL) and for conventional production - pesticide costs, fuel costs (YTL), labour costs (YTL) and other costs) and one output (the amount of olives). The obtained result was that farms with conventional production method have lower efficiency. The aggregate data of the FADN (Farm Accountancy Data Network) have been used for analysing of the dynamics of productivity efficiency of 8 types of farms and an average value in Lithuania for the period from 2003 to 2010 (Baležentis, Kriščiukaitienè, 2012). The analysis has shown that the average efficiency of a Lithuanian farm ranges from $76.5 \%$ to $92.2 \%$ during 2003-2010. Mixed cattle and plant production showed the highest technical efficiency for the given period. The analysis showed the low level of productivity of land, depreciation of assets and consumption of intermediate production mainly affect the inefficiency. Large farms operate more efficiently.

There are a number of studies that have analysed the operation of farms/holdings. Jankovic and associates (2006) has used the gross margin for the evaluation of operation of farms/ holdings. The study was conducted on 300 family farms in 2006 in order to obtain gross margin of some production lines. The research has shown that the best manufacturers pay much more attention to every stage of production and sales, use smaller quantities of seeds, fertilizers and pesticides per ha and purchase them at lower prices, and they achieve significant revenues with good yield and sell at higher prices. De Bont and associates (2003) in their report, determine the economic size of agricultural holdings of the Netherlands. The main source of data for the calculation of the standard gross margin is a national system of accounting data (FADN). The value of standard gross margin of crop products was reduced by the value of the straw, while the straw value was included in the value of other crops. In that time, the average gross margin of crop production was 1,000 EUR/ha. The basic division of mathematical programming models in animal husbandry can be carried out on optimization and simulation models (Stygar, Makulska, 2010). This research was conducted using the mathematical programming in production management in beef fattening. Optimization models are used in cases where it is necessary to determine the optimal structure of production, and simulation models are used for studying the behaviour of the system over time under various conditions. A model of farm that deals with cattle production, with the focus on the production of milk production was analysed (Vico, 2012). The farm focuses on milk production represent production system with livestock and crop production lines, which are forage base for dairy cattle and breeding offspring. Applying linear programming the optimal production structure was obtained and it will greatly contribute to the realization of the extreme values of a given optimality criterion. Krasnić (2008) was involved in formulating a model for optimizing the structure of vegetable production. Model for optimizing the structure of vegetable production worked in two ways. One is the optimization of the structure of vegetable production for industrial processing and is applicable to agricultural enterprises. 
Second variant is related to the optimization of the structure of vegetable production for direct consumption in the fresh condition, and is applicable to private farms. In addition to providing quality and relevant brand of vegetable products for the European market, it would mean the reality of enlargement area and yield increase under vegetables to the real participation from $10 \%$ to $18 \%$ of arable land. The FADN data were successfully used for estimation the efficiency of different region in Turkish (Atici, Podinovski, 2015). They used four inputs: land, labour, crop production costs and capital expenditures. The productions of 36 different crops were used as outputs in their DEA model. Another example is the research done in India, where agriculture depends mostly on the efficiency of using the groundwater for irrigation. Manjunatha and associates (2011) considered the three groups of water users: water sellers, water buyers and control group and estimated their efficiency. The first group-water sellers are proved to be less efficient than the second but more efficient than control group, consisting of farmers which have their own water and are not engaged in selling and buying water. They used the data relating to the amount of water, irrigated area, labour, machine power, manure, fertilizers and gross returns. The energy efficiency is the topic that attracts much attention nowadays. Bolandnazar and associates (2014) used data envelopment analisys approach to calculate the efficiency of the cucumber greenhouses production from energy consumption point of view.

\section{Method of research and data sources}

Nonparametric DEA method is based on a linear programming model for evaluation of the efficiency limits. The basic DEA model was set in 1978 (Charnes et al., 1978). It has been modified and expanded over years, so the model proposed by them is denoted now as CCR. By this model the multiple inputs are reduced to a single 'virtual' input and multiple outputs are reduced to a single 'virtual' output using weights (weight coefficients). In the defined model, the organizational unit for which the efficiency is being estimated is called DMU (decision Making Unit) or decision unit or units to be decided. DEA method enables to determine the relative efficiency in comparison to other entities that are involved in the analysis for each one of the entities on the basis of its input and output data. While selecting units for evaluation of efficiency it should be taken into account the fact that they have to be of the same type. In fact, small and large organizational units in this model should not be compared, because they are qualitatively different and it can distort the measure of the efficiency comparisons.

For output-oriented models, which are used in the present paper, the goal is to maximize output for a given level of inputs. In this model, $\mathrm{DMU}_{k}$ is considered relatively inefficient if it is possible to increase any output without increasing input and without decreasing any other output. Inefficient unit becomes efficient if it increases each output proportional to the factor of intensity $\theta_{\mathrm{k}}$ from the dual model. In addition to these two orientations there is a so called un-oriented model (Cooper et al., 2007).

CCR model assumes that the increment of output relative to the input is constant [constant returns to scale (CRS)], meaning that the relationship is linear. The first extension of CCR model was given by (Banker et al., 1984), and designated/identified 
as BCC. This model assumes that the response is variable [variable return to scale (VRS)], meaning that the relationship is curvilinear and it is a non-increasing response model [non-increasing return to scale (NIRS)].

For definition of this model, the $n \mathrm{DMU}_{k} ; k=1,2, \ldots, n$ with $m$ inputs $x_{j k}>0 ; j=1,2, \ldots, m$ and $s$ outputs for each of them, are observed.

For each $\mathrm{DMU}_{k}, k=1,2, \ldots, n$ the relative efficiency is defined as

$$
h_{k}=\frac{\sum_{r=1}^{s} u_{r k} y_{r k}}{\sum_{i=1}^{m} v_{i k} x_{i k}} ; k=1,2, \ldots, n
$$

Where the weights $v_{i k}$ present the value (quantitatively expressed importance) of the $i$-th input for each $\mathrm{DMU}_{k}$, and $u_{r k}$ present the value (quantitatively expressed importance) of the $r$-th output for each $\mathrm{DMU}_{k}$. Thus defined efficiency refers to the set of observed DMU, and therefore reflects the relative efficiency and it is a number between 0 and 1 . The weights are determined for each DMUk independently to maximize its efficiency relative to other DMU that are included in the analysis.

In this paper, the $\mathrm{CCR}$ and $\mathrm{BCC}$ models will be used to determine the efficiency. CCR model determines the total technical efficiency (TE), which includes pure technical efficiency (PTE) and scale efficiency (SE), which is a consequence of the different business volume. The measure of efficiency obtained by this model is still less or equal to those obtained by the CCR model.

The dual task of the input-oriented model is used for evaluation of efficiency measure

$$
[\min ] \theta_{k}-\varepsilon\left(\sum_{r=1}^{s} s_{r k}^{+}+\sum_{i=1}^{m} s_{i k}^{-}\right)
$$

With constraints

$$
\begin{gathered}
\theta_{k} \cdot x_{i k}-\sum_{j=1}^{n} \lambda_{j k} x_{i j}-s_{i k}^{-}=0 ; i=1,2, \ldots, m \\
\sum_{j=1}^{n} \lambda_{j k} y_{r j}-s_{i k}^{+}=y_{r k} ; r=1,2, \ldots, s \\
\lambda_{j k} \geq 0 ; j=1,2, \ldots, n ; r=1,2, \ldots, s ; i=1,2, \ldots, m ; \quad \theta_{k}-\text { no restrictions }
\end{gathered}
$$

For the BCC model, there is a further restriction, namely: $\sum_{j=1}^{n} \lambda_{j k}=1$ when there is no restriction for variable increment or $\sum_{j=1}^{n} \lambda_{j k} \leq 1$ for non-increasing gain or $\sum_{j=1}^{n} \lambda_{j k} \geq 1$ for non-decreasing gain.

EP 2015 (62) 3 (781-799) 
If $\theta_{k}^{*}=1$ and when all the additional variables $s_{i k}^{-*}$ and $s_{i k}^{+*}$ are equal to zero, it will be $h_{k}^{*}=1$ and the corresponding DMUk is completely (strong) efficient, it is so called Pareto-Koopman's efficiency: DMU fully efficient if and only if it is not possible to improve any input or output without violating another input or output. If $\theta_{k}^{*}=1$ and there are also $s_{r k}^{+*}$ and $s_{i k}^{-*}$ which are nonzero values, then $\mathrm{DMU}_{k}$ is border point but is not efficient (not fully enveloped). Such DMU is said to be weakly efficient.

For each inefficient DMU, moving towards the limits of efficiency, in the inputoriented model, is determined by the system of equations

$$
\begin{aligned}
& \sum_{j=1}^{n} \lambda_{j k}^{*} x_{i j}+s_{i k}^{-^{*}}=\theta_{k}^{*} \cdot x_{i k} ; i=1,2, \ldots, m \\
& \sum_{j=1}^{n} \lambda_{j k}^{*} y_{r j}-s_{i k}^{+^{*}}=y_{r k} ; r=1,2, \ldots, n
\end{aligned}
$$

Scale efficiency can be obtained as the quotient of measure of the efficiency obtained by the CCR model and measure of the efficiency obtained by the BCC model.

$$
S E_{k}=\frac{h_{k(C C R)}^{*}}{h_{k(B C C)}^{*}}
$$

If $S E_{k}=1$ then the corresponding $\mathrm{DMU}_{k}$ is scale efficient, and if $S E_{k}<1$ it is scale inefficient.

Thus determined measure of efficiency is relative because it depends on the number of entities involved in the analysis and the number and structure of inputs and outputs. The main disadvantage of this analysis is that the introduction of a new DMU requires re-calculation of the relative efficiency and previously obtained conclusions can be completely changed. Also, the efficiency limit evaluated with DEA is sensitive to measurement errors or other problems that may arise with the data. DEA assessment does not provide any guidance on statistical reasoning.

In this paper the data relate to three groups of 20 individual farms with different types of production from the municipalities of Prokuplje, Žitorađa, Blace and Kursumlija were analysed as the main data source. The planned selection of farms enabled the definition of several farm models of different sizes and different production structures. Surveyed farms/holdings were selected according to the total agricultural area per municipality as well as the dominant productions in certain municipalities and urban areas. Thus, in the largest municipality of Prokuplje, a total of 22 farms were surveyed, from which 8 were with dominant fruit production, 7 with a dominant crop and vegetable productions and 7 with the dominant livestock production. In the municipality of Blace, a total of 14 farms were surveyed and that is 6 with dominant fruit production, 3 with the dominant crop and vegetable productions and 5 with the dominant livestock production. In the 
municipality of Kursumlija, the survey covered a total of 11 farms, 3 with the dominant fruit production, 3 with the dominant crop and vegetable productions and 5 with the dominant livestock production. The municipality Žitorađa covered a total of 13 farms, of which 3 with the dominant fruit production, 7 with the dominant crop and vegetable productions, and 3 with the dominant livestock production.

Data were collected in 2011 through a survey, which was designed so that the owners or managers answer the questions. Questions were related to the input elements of the system as well as to the output elements. Establishing of realized operating results and the calculation of income and expense of family households were done by analytical calculations. All calculations were obtained in period from 2013 to 2014, based on prices from 2010 (Orović, 2014).

\section{Empirical implementation}

In this paper, the variables used as input for the implementation of the chosen model, and based on the data obtained in the survey were:

- $\quad$ total land used ha (I1)

- material costs from non-primary production RSD (I2)

- total cost of materials and maintenance of RSD (I3)

- the total cost of services RSD (I4),

and the output variables observed, depending on the model, were:

- the value of primary production RSD (O1)

- the value of non-primary production RSD (O2)

For the DMU mark, first two characters represent the number of the farm 1-60, the third character specifies the type of production (f-fruit, c-crop and vegetable, 1-livestock) and the fourth is the first letter of the municipality. The data was processed using software DEA-Solver-Pro (Professional Version 9.0) and Statistica 12. During the calculation, Dea Solver Pro replaced negative values with a small positive number which is not counted in efficiency.

Descriptive statistics for the analysed inputs and outputs for each group of holdings are given in Table1. 
Table 1. Descriptive Statistics

\begin{tabular}{|c|c|c|c|c|c|c|c|c|}
\hline $\mathrm{tp}^{0}$ & $\mathrm{I} / \mathrm{O}$ & Min & Max & Mean & $\begin{array}{l}\text { Std. } \\
\text { Dev. }\end{array}$ & $\begin{array}{c}\text { Cf.var } \\
\% \\
\end{array}$ & Skewness & Kurtosis \\
\hline \multirow{6}{*}{$\mathrm{F}$} & $\begin{array}{l}\text { Total land used ha } \\
\text { (I1) }\end{array}$ & 2.2 & 20 & 9 & 4 & 45.99 & 0.643 & 0.617 \\
\hline & $\begin{array}{l}\text { Material cost } \\
\text { from non-primary } \\
\text { production RSD (I2) }\end{array}$ & 0.0 & 916,800 & 249,390 & 241,739 & 96.93 & 1.165 & 1.384 \\
\hline & $\begin{array}{l}\text { Total cost of material } \\
\text { and maintenance } \\
\text { RSD (I3) }\end{array}$ & 251,600 & $1,666,800$ & 831,926 & 368,461 & 44.29 & 0.346 & -0.237 \\
\hline & $\begin{array}{l}\text { Total cost of services } \\
\text { RSD (I4) }\end{array}$ & 110,000 & $1,485,000$ & 711,675 & 422,950 & 59.43 & 0.418 & -1.054 \\
\hline & $\begin{array}{l}\text { The value of } \\
\text { primary production } \\
\text { RSD (O1) }\end{array}$ & 625,000 & $7,800,000$ & $3,173,575$ & $1,911,495$ & 60.23 & 0.612 & 0.072 \\
\hline & $\begin{array}{l}\text { The value of non- } \\
\text { primary production } \\
\text { RSD (O2) }\end{array}$ & 0.0 & $2,513,200$ & 808,348 & 736,951 & 91.17 & 0.782 & -0.253 \\
\hline \multirow{6}{*}{$\mathrm{C}$} & $\begin{array}{l}\text { Total land used } h a \\
\text { (I1) }\end{array}$ & 4.0 & 22 & 8 & 4 & 57.76 & 2.142 & 4.905 \\
\hline & $\begin{array}{l}\text { Material cost } \\
\text { from non-primary } \\
\text { production RSD (I2) }\end{array}$ & 0.0 & 120,000 & 33,750 & 40,681 & 120.54 & 0.867 & -0.515 \\
\hline & $\begin{array}{l}\text { Total cost of material } \\
\text { and maintenance RSD } \\
\text { (I3) }\end{array}$ & $333,000.0$ & $1,719,750$ & 810,295 & 435,024 & 53.69 & 0.832 & -0.580 \\
\hline & $\begin{array}{l}\text { Total cost of services } \\
\text { RSD (I4) }\end{array}$ & $190,000.0$ & $1,030,000$ & 427,950 & 241,731 & 56.49 & 1,391 & 1.232 \\
\hline & $\begin{array}{l}\text { The value of } \\
\text { primary production } \\
\text { RSD (O1) }\end{array}$ & $339,000.0$ & $6,062,500$ & $1,798,600$ & $2,012,805$ & 111.91 & 1.362 & 0.248 \\
\hline & $\begin{array}{l}\text { The value of non- } \\
\text { primary production } \\
\text { RSD (O2) }\end{array}$ & 0.0 & $4,558,000$ & $1,014,500$ & $1,084,143$ & 106.86 & 2.135 & 5.519 \\
\hline \multirow{6}{*}{$\mathrm{L}$} & $\begin{array}{l}\text { Total land used } h a \\
\text { (I1) }\end{array}$ & 5.5 & 35 & 17 & 8 & 49.38 & 0.595 & -0.652 \\
\hline & $\begin{array}{l}\text { Material cost } \\
\text { from non-primary } \\
\text { production RSD (I2) }\end{array}$ & $220,000.0$ & $1,658,000$ & 847,010 & 477,527 & 56.38 & 0.241 & -1.176 \\
\hline & $\begin{array}{l}\text { Total cost of material } \\
\text { and maintenance RSD } \\
\text { (I3) }\end{array}$ & $412,550.0$ & $9,992,000$ & $1,486,898$ & $2,036,540$ & 136.97 & 4.224 & 18.454 \\
\hline & $\begin{array}{l}\text { Total cost of services } \\
\text { RSD (I4) }\end{array}$ & $130,000.0$ & $1,140,000$ & 553,025 & 298,282 & 53.94 & 0.566 & -0.545 \\
\hline & $\begin{array}{l}\text { The value of } \\
\text { primary production } \\
\text { RSD (O1) }\end{array}$ & $726,000.0$ & $11,280,000$ & $3,301,440$ & $2,454,228$ & 74.34 & 1.801 & 4.997 \\
\hline & $\begin{array}{l}\text { The value of non- } \\
\text { primary production } \\
\text { RSD (O2) }\end{array}$ & $331,000.0$ & $2,533,500$ & $1,483,828$ & 626,149 & 42.20 & -0.141 & -0.489 \\
\hline
\end{tabular}

Note: $\mathrm{tp}^{0}=$ type of production

Source: Authors' calculation according to data from Orović (2014).

Considering the deviation from the normal of the observed distribution, Spearman's rank correlation coefficients were calculated (Table 2), and based on them it is obvious that there was no correlation between the selected outputs. 
Table2. Correlations

\begin{tabular}{|c|c|c|c|c|c|c|c|}
\hline $\begin{array}{c}\text { Type of } \\
\text { Production }\end{array}$ & $\mathbf{I} / \mathbf{O}$ & I1 & I2 & I3 & I4 & 01 & $\mathbf{O 2}$ \\
\hline \multirow{6}{*}{$\mathrm{F}$} & I1 & 1.0000 & 0.3379 & $0.7094 * *$ & $0.6000 * *$ & $0.5668 * *$ & 0.4370 \\
\hline & $\mathrm{I} 2$ & 0.3379 & 1.0000 & 0.0994 & 0.0482 & -0.1928 & $0.5316^{* *}$ \\
\hline & I3 & $0.7094 * *$ & 0.0994 & 1.0000 & $0.9083^{* *}$ & $0.7759 * *$ & $0.1308 * *$ \\
\hline & I4 & $0.6000 * *$ & 0.0482 & $0.9083 * *$ & 1.000000 & $0.8722 * *$ & -0.0105 \\
\hline & $\mathrm{O} 1$ & $0.5668 * *$ & -0.1923 & $0.7759 * *$ & $0.8722 * *$ & 1.0000 & -0.1383 \\
\hline & $\mathrm{O} 2$ & 0.4370 & $0.5316^{* *}$ & 0.130827 & -0.0105 & -0.1383 & 1.0000 \\
\hline \multirow{6}{*}{$\mathrm{C}$} & I1 & 1.0000 & $0.5508 * *$ & $0.6244 * *$ & $0.6113 * *$ & 0.2514 & $0.7153 * *$ \\
\hline & $\mathrm{I} 2$ & $0.5508^{*}$ & 1.0000 & 0.3083 & 0.1131 & -0.1703 & $0.7538 * *$ \\
\hline & I3 & $0.6244 * *$ & 0.3083 & 1.0000 & $0.7133 * *$ & $0.6752 * *$ & 0.3148 \\
\hline & I4 & $0.6113 * *$ & 0.1131 & $0.7133 * *$ & 1.0000 & $0.5576^{*}$ & 0.3253 \\
\hline & $\mathrm{O} 1$ & 0.2514 & -0.1703 & $0.6752 * *$ & $0.5576^{*}$ & 1.0000 & -0.1442 \\
\hline & $\mathrm{O} 2$ & $0.7153 * *$ & $0.7538 * *$ & 0.3148 & 0.3253 & -0.1442 & 1.0000 \\
\hline \multirow{6}{*}{$\mathrm{L}$} & I1 & 1.0000 & $0.7722 * *$ & $0.5284 *$ & $0.6436^{* *}$ & $0.6724 * *$ & $0.5450 *$ \\
\hline & I2 & $0.7722^{* *}$ & 1.0000 & 0.3091 & $0.6604 * *$ & $0.7931 * *$ & 0.3182 \\
\hline & I3 & $0.5284^{*}$ & 0.3091 & 1.0000 & 0.2195 & $0.5318^{*}$ & 0.1985 \\
\hline & I4 & $0.6436^{* *}$ & $0.6604 * *$ & 0.2195 & 1.0000 & $0.7424 * *$ & $0.6150 * *$ \\
\hline & $\mathrm{O} 1$ & $0.6724 * *$ & $0.7931 * *$ & $0.5318^{* *}$ & $0.7424 * *$ & 1.0000 & 0.4325 \\
\hline & $\mathrm{O} 2$ & $0.5450^{*}$ & 0.3182 & 0.1985 & 0.6150 & 0.4324 & 1.0000 \\
\hline
\end{tabular}

Note: the significance is marked with $*$ for the $\mathrm{p}<0.05$, and $* *$ for the $\mathrm{p}<0.01$

Source: Authors' calculation according to data from Orović (2014).

Table 3 shows the results of the analysis for the observed DEA group. 
Table 3. Efficiency and corresponding DMU for the observed models

\begin{tabular}{|c|c|c|c|c|c|c|c|}
\hline $\operatorname{tp}^{0}$ & DMU & $\mathrm{TE}$ & CTE & SE & Corresponding set for CCR & RTS & $\begin{array}{c}\text { RTS of Proj } \\
\text { DMU }\end{array}$ \\
\hline \multirow{24}{*}{$\mathrm{F}$} & $1 \mathrm{fp}$ & 0.8374 & 0.8458 & 0.9901 & 8fp (0.726); 10fp (0.321) & & $\mathrm{dcr}^{1}$ \\
\hline & $2 \mathrm{fp}$ & 1 & 1 & 1 & $2 \mathrm{fp}-\mathbf{0}^{4}$ & $\operatorname{con}^{2}$ & \\
\hline & $3 \mathrm{fp}$ & 0.9016 & 0.9294 & 0.97 & $8 \mathrm{fp}(0.570) ; 10 \mathrm{fp}(0.057)$ & & con \\
\hline & $4 \mathrm{fp}$ & 1 & 1 & 1 & $4 f p-4$ & con & \\
\hline & $5 \mathrm{fp}$ & 0.7878 & 0.7912 & 0.9957 & 4fp (0.02); 10fp (0.634);19fp (0.187) & & con \\
\hline & $6 \mathrm{fp}$ & 0.5560 & 0.5735 & 0.9694 & $4 \mathrm{fp}(0.558) ; 13 \mathrm{fp}(0.103) ; 19 \mathrm{fp}(0.688)$ & & der \\
\hline & $7 \mathrm{fp}$ & 0.8008 & 0.8155 & 0.9819 & $4 \mathrm{fp}(0.543) ; 19 \mathrm{fp}(0.616)$ & & der \\
\hline & $8 \mathrm{fp}$ & 1 & 1 & 1 & $8 f p-6$ & con & \\
\hline & $9 \mathrm{fz}$ & 0.6843 & 0.6888 & 0.9935 & $8 \mathrm{fp}(0.450) ; 13 \mathrm{fp}(0.067) ; 19 \mathrm{fp}(0.444)$ & & con \\
\hline & $10 \mathrm{fz}$ & 1 & 1 & 1 & $10 \mathrm{fp}-\mathbf{5}$ & con & \\
\hline & $11 \mathrm{fz}$ & 0.7244 & 0.7248 & 0.9994 & $8 \mathrm{fp}(0.533) ; 10 \mathrm{fp}(0.215) ; 13 \mathrm{fp}(0.0157)$ & & con \\
\hline & $12 \mathrm{fb}$ & 1 & 1 & 1 & $12 \mathrm{fp}-1$ & con & \\
\hline & $13 \mathrm{fb}$ & 1 & 1 & 1 & $13 f p-6$ & con & \\
\hline & $14 \mathrm{fb}$ & 0.6178 & 0.6530 & 0.9461 & $19 \mathrm{fp}(0.150) ; 20 \mathrm{fp}(0.703)$ & & con \\
\hline & $15 \mathrm{fb}$ & 0.4530 & 0.5720 & 0.792 & 4fp (0.069); 13fp (0.517); 19fp (0.150) & & con \\
\hline & $16 \mathrm{fb}$ & 0.9079 & 1 & 0.9079 & 8fp (0.699); 19fp (1.389) & dcr & \\
\hline & $17 \mathrm{fb}$ & 0.5447 & 0.5465 & 0.9968 & $8 \mathrm{fp}(0.206) ; 10 \mathrm{fp}(0.347) ; 13 \mathrm{fp}(0.111)$ & & con \\
\hline & $18 \mathrm{fk}$ & 0.6805 & 0.8288 & 0.8211 & $12 \mathrm{fp}(0.191) ; 13 \mathrm{fp}(0.316) ; 19 \mathrm{fp}(0.160)$ & & con \\
\hline & $19 \mathrm{fk}$ & 1 & 1 & 1 & $19 f p-8$ & con & \\
\hline & $20 \mathrm{fk}$ & 1 & 1 & 1 & $20 \mathrm{fp}-1$ & con & \\
\hline & Mean & 0.8248 & 0.8485 & 0.9682 & & & \\
\hline & SD & 0.1793 & 0.1643 & 0.0586 & & & \\
\hline & $\operatorname{Max}$ & 1 & 1 & 1 & & & \\
\hline & Min & 0.4530 & 0.5465 & 0.792 & & & \\
\hline
\end{tabular}




\begin{tabular}{|c|c|c|c|c|c|c|c|}
\hline $\operatorname{tp}^{0}$ & DMU & $\mathrm{TE}$ & CTE & SE & Corresponding set for CCR & RTS & $\begin{array}{l}\text { RTS of Proj } \\
\text { DMU }\end{array}$ \\
\hline \multirow{24}{*}{$\mathrm{C}$} & $21 \mathrm{cp}$ & 0.6433 & 0.7919 & 0.8124 & $28 \mathrm{cz}(0.024) ; 37 \mathrm{cp}(0.751)$ & & icr $^{3}$ \\
\hline & $22 \mathrm{cp}$ & 0.5430 & 0.6763 & 0.8029 & $\begin{array}{l}25 \mathrm{cp}(0.134) ; 28 \mathrm{cz}(0.027) ; 33 \mathrm{cz}(0.051) ; 36 \mathrm{cb} \\
(0.086) ; 37 \mathrm{cb}(0.033)\end{array}$ & & Icr \\
\hline & $23 \mathrm{cp}$ & 0.3736 & 0.7948 & 0.4701 & 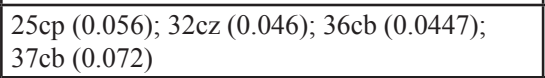 & & icr \\
\hline & $24 \mathrm{cp}$ & 0.8065 & 1 & 0.8065 & $25 \mathrm{cp}(0.035) ; 32 \mathrm{cz}(0.024) ; 36 \mathrm{cb}(0.223)$ & icr & \\
\hline & $25 \mathrm{cp}$ & 1 & 1 & 1 & $25 \mathrm{cp}-4$ & con & \\
\hline & $26 \mathrm{cp}$ & 0.7417 & 0.8466 & 0.8761 & $32 \mathrm{cz}(0.141) ; 36 \mathrm{cb}(0.327)$ & & icr \\
\hline & $27 \mathrm{cp}$ & 0.7035 & 0.7465 & 0.9424 & $33 \mathrm{cz}(0.053) ; 36 \mathrm{cb}(0.437)$ & & icr \\
\hline & $28 \mathrm{cz}$ & 1 & 1 & 1 & $28 \mathrm{cz}-\mathbf{3}$ & con & \\
\hline & $29 \mathrm{cz}$ & 0.7232 & 1 & 0.7232 & $\begin{array}{l}28 \mathrm{cz}(0.267) ; 32 \mathrm{cz}(0.470) ; 33 \mathrm{cz}(0.197) ; 37 \mathrm{cb} \\
(0.618)\end{array}$ & der & \\
\hline & $30 \mathrm{cz}$ & 0.3505 & 1 & 0.3505 & $32 \mathrm{cz}(0.019) ; 33 \mathrm{cz}(0.116)$ & icr & \\
\hline & $31 \mathrm{cz}$ & 0.5867 & 0.7398 & 0.7931 & $32 \mathrm{cz}(0.043) ; 33 \mathrm{cz}(0.05) ; 37 \mathrm{cb}(0.566)$ & & icr \\
\hline & $32 \mathrm{cz}$ & 1 & 1 & 1 & $32 \mathrm{cz}-9$ & con & \\
\hline & $33 \mathrm{cz}$ & 1 & 1 & 1 & $33 c z-9$ & con & \\
\hline & $34 \mathrm{cz}$ & 0.6672 & 0.8648 & 0.7715 & $32 \mathrm{cz}(0.169) ; 33 \mathrm{cz}(0.345)$ & & icr \\
\hline & $35 \mathrm{cb}$ & 0.5835 & 0.965 & 0.6046 & $\begin{array}{l}25 \mathrm{cp}(0.082) ; 32 \mathrm{cz}(0.011) ; 33 \mathrm{cz}(0.017) ; 36 \mathrm{cb} \\
(0.09)\end{array}$ & & icr \\
\hline & $36 \mathrm{cb}$ & 1 & 1 & 1 & $36 \mathrm{cb}-7$ & con & \\
\hline & $37 \mathrm{cb}$ & 1 & 1 & 1 & $37 \mathrm{cb}-6$ & con & \\
\hline & $38 \mathrm{ck}$ & 1 & 1 & 1 & $38 \mathrm{ck}-\mathbf{0}$ & con & \\
\hline & $39 \mathrm{ck}$ & 0.6623 & 0.9737 & 0.6801 & $33 \mathrm{cz}(0.62) ; 36 \mathrm{cb}(0.151)$ & & icr \\
\hline & $40 \mathrm{ck}$ & 0.5292 & 1 & 0.5292 & $32 \mathrm{cz}(0.0004) ; 33 \mathrm{cz}(0.03) ; 37 \mathrm{cb}(0.400)$ & icr & \\
\hline & Mean & 0.7457 & 0.9200 & 0.8081 & & & \\
\hline & $\mathrm{SD}$ & 0.2140 & 0.1090 & 0.1934 & & & \\
\hline & $\operatorname{Max}$ & 1 & 1 & 1 & & & \\
\hline & Min & 0.3505 & 0.6763 & 0.3505 & & & \\
\hline
\end{tabular}




\begin{tabular}{|c|c|c|c|c|c|c|c|}
\hline $\operatorname{tp}^{0}$ & DMU & $\mathrm{TE}$ & CTE & SE & Corresponding set for CCR & RTS & $\begin{array}{l}\text { RTS of Proj } \\
\text { DMU }\end{array}$ \\
\hline \multirow{24}{*}{$\mathrm{L}$} & $411 \mathrm{p}$ & 1 & 1 & 1 & $411 p-2$ & con & \\
\hline & $421 \mathrm{p}$ & 1 & 1 & 1 & $421 p-4$ & con & \\
\hline & $431 \mathrm{p}$ & 0.8743 & 1 & 0.8743 & 42lp (0.025);54lb (1.123); 591k (0.294) & der & \\
\hline & $441 \mathrm{p}$ & 1 & 1 & 1 & $441 p-3$ & con & \\
\hline & $451 \mathrm{p}$ & 0.8949 & 0.9932 & 0.901 & $\begin{array}{l}\text { 44lp (0.081); 46lp (0.106); 47lp (0.382);59lk } \\
(0.039)\end{array}$ & & icr \\
\hline & $461 \mathrm{p}$ & 1 & 1 & 1 & $461 p-3$ & con & \\
\hline & $47 \mathrm{p}$ & 1 & 1 & 1 & $471 p-6$ & con & \\
\hline & $481 \mathrm{z}$ & 1 & 1 & 1 & $481 z-0$ & con & \\
\hline & $491 \mathrm{z}$ & 1 & 1 & 1 & $491 z-1$ & con & \\
\hline & $501 \mathrm{z}$ & 1 & 1 & 1 & $501 z-5$ & con & \\
\hline & $511 \mathrm{~b}$ & 1 & 1 & 1 & $511 \mathrm{~b}-1$ & con & \\
\hline & $521 \mathrm{~b}$ & 0.8093 & 0.8166 & 0.9912 & $\begin{array}{l}\text { 44lp (0.113); 46lp (0.222); 47lp (0.229); 54lb } \\
(0.190) ; 591 \mathrm{k}(0.087)\end{array}$ & & icr \\
\hline & $531 \mathrm{~b}$ & 0.9876 & 1 & 0.9876 & $411 \mathrm{p}(0.627) ; 501 \mathrm{z}(0.008) ; 591 \mathrm{k}(0.681)$ & der & \\
\hline & $541 \mathrm{~b}$ & 1 & 1 & 1 & $541 \mathrm{~b}-\mathbf{5}$ & con & \\
\hline & $55 \mathrm{lb}$ & 0.9217 & 1 & 0.9217 & $\begin{array}{l}\text { 41lp (0.037); 47lp (0.636); 501z (0.020); 59lk } \\
(0.535)\end{array}$ & der & \\
\hline & $561 \mathrm{k}$ & 0.6687 & 0.6689 & 0.9998 & $\begin{array}{l}\text { 44lp (0.133); 47lp (0.547); 51lb (0.054); 59lk } \\
(0.261)\end{array}$ & & con \\
\hline & $571 \mathrm{k}$ & 0.5383 & 0.8824 & 0.61 & $\begin{array}{l}42 \operatorname{lp~(0.128);~46lp~(0.098);~49lz~(0.018);~50lz~} \\
(0.0006) ; 541 \mathrm{l}(0.113)\end{array}$ & & icr \\
\hline & $58 \mathrm{lk}$ & 0.6387 & 1 & 0.6387 & $\begin{array}{l}42 \mathrm{lp}(0.015) ; 47 \mathrm{lp}(0.098) ; 50 \mathrm{lz}(0.006) ; 54 \mathrm{lb} \\
(0.092) ; 591 \mathrm{k}(0.031)\end{array}$ & ict & \\
\hline & $591 \mathrm{k}$ & 1 & 1 & 1 & $591 \mathrm{k}-\mathbf{8}$ & con & \\
\hline & $60 \mathrm{lk}$ & 0.4811 & 0.6449 & 0.7461 & $\begin{array}{l}42 \operatorname{lp}(0.151) ; 47 \mathrm{lp}(0.177) ; 50 \mathrm{lz}(0.015) ; 54 \mathrm{lb} \\
(0.015) ; 591 \mathrm{k}(0.014)\end{array}$ & & icr \\
\hline & Mean & 0.8907 & 0.9503 & 0.9335 & & & \\
\hline & SD & 0.1663 & 0.1081 & 0.1206 & & & \\
\hline & Max & 1 & 1 & 1 & & & \\
\hline & Min & 0.4811 & 0.6449 & 0.61 & & & \\
\hline
\end{tabular}

Note: ${ }^{0} \mathrm{tp}=$ type of production; ${ }^{1} \mathrm{dcr}=$ decreasing; ${ }^{2} \mathrm{con}=$ constant $;{ }^{3} \mathrm{icr}=$ increasing; ${ }^{4}$ frequency in Reference Set

Source: Authors' calculation according to data from Orović (2014).

Results indicate that in the observed group, agricultural holdings $2 \mathrm{fp}, 4 \mathrm{fp}, 8 \mathrm{fp}, 10 \mathrm{fz}$, $12 \mathrm{fb}, 13 \mathrm{fb}, 19 \mathrm{fk}, 20 \mathrm{fk}$ are efficient, the remaining 12 holdings $(1 \mathrm{fp}, 3 \mathrm{fp}, 5 \mathrm{fp}, 6 \mathrm{fp}, 7 \mathrm{fp}$, $9 \mathrm{fz}, 11 \mathrm{fz}, 14 \mathrm{fb}, 15 \mathrm{fb}, 16 \mathrm{fb}, 17 \mathrm{fb}$ and $18 \mathrm{fk}$ ) are inefficient. The results for the surveyed rural holdings from Toplice region with dominant fruit production show that it has an enviable efficiency score, but it can be even better if the input variables (cost) are reduced. An example of good practice could be agricultural holdings $10 \mathrm{fz}, 13 \mathrm{fb}, 19 \mathrm{fk}$ and $20 \mathrm{fk}$ which are reference for most households.

The main characteristics of the holding 10fz are: it is in Žitorađa and it has a dominant 
cherry production, two-thirds of total fruit production, with good yield of $15,000 \mathrm{~kg}$ per hectare and with a price of 80.00 dinars per kilogram. This holding also produces peppers on $1.5 \mathrm{ha}$, as non-dominant production. It has all the necessary machinery for cultivation, it works with three family members, redistribution of land on this farm provided smaller cost of land cultivation, and the fact that it is in urban area reduces the transportation cost of product delivery to the market.

The farm $13 \mathrm{fb}$ is located in the vicinity of Blace at a slightly higher altitude, it has a small area of land on which mostly late fruit is grown and this holding is achieving a higher price in the market (cherry $90 \mathrm{RSD}$, apple $40 \mathrm{RSD}$ and plum $27 \mathrm{RSD}$ for $\mathrm{kg}$ ), it has all the equipment and family labour (three members).

Holding 19fk is located in the vicinity of Kuršumlija. It has plums as the dominant production and it achieves high yield and good price. In addition to plum production, there are 120 beehives as a non-dominant production of honey which has a high yield and low cost due to natural advantages of the farm location.

There are 7 efficient farms in crop production. The results have shown that in the observed group, 7 agricultural holdings $(25 \mathrm{cp}, 28 \mathrm{cz}, 32 \mathrm{cz}, 33 \mathrm{cz}, 36 \mathrm{cb}, 37 \mathrm{cb}, 38 \mathrm{ck})$ achieve efficiency in business, and the remaining 13 holdings $(21 \mathrm{cp}, 22 \mathrm{cp}, 23 \mathrm{cp}$, $24 \mathrm{CP}, 26 \mathrm{cp}, 27 \mathrm{cp}, 29 \mathrm{cz}, 30 \mathrm{cz}, 31 \mathrm{cz}, 34 \mathrm{cz}, 35 \mathrm{cb}, 39 \mathrm{ck}$ and $40 \mathrm{ck})$ are inefficient. The results of the surveyed rural holdings engaged in crop and vegetable production from Toplice region have shown that they have an enviable efficiency score, but it can be even better if the input variables (cost) are reduced. An example of good practice could be agricultural holdings $28 \mathrm{cz}, 32 \mathrm{cz}, 33 \mathrm{cz}, 36 \mathrm{cb}$ and $37 \mathrm{cb}$ which are reference for most households.

The holding $28 \mathrm{cz}$ is located in the vicinity of Žitoradja, it is engaged in vegetable production on half of its agricultural land (melons, tomatoes, tomato greenhouse), and the other half is planted with corn and wheat, this is mainly due to crop rotation. It achieves good prices in the market, and also in direct sale on the farm. It has all the necessary machinery for cultivation, five family members engaged in the production, redistribution of land on this farm has reduced the cost of land cultivation. The average plot is 1 ha.

The farm $32 \mathrm{cz}$ is also located in the vicinity of Žitoradja. It is engaged in vegetable production of greenhouse peppers, greenhouse tomatoes and melons and also the corn and wheat are present, mainly due to crop rotation. Greenhouse production enables a good profit, and melon completes the season with high yields due to the use of modern agricultural technology.

The farm 33cz, as the previous two farms, is near Žitoradja and it is mainly engaged in vegetable production - melon on 4ha, and corn and wheat, mainly due to crop rotation.

The farm $36 \mathrm{cb}$ is in the vicinity of Blace. It is engaged in crop production mainly for the supply of feed for own dairy farm, and the surplus is sold. This farm produces plum on 4 ha. The input costs are reduced due to ownership of the land/farm. It has all the necessary machinery for cultivation and eight family members who are engaged in the production. 
The farm $37 \mathrm{cb}$ is in the vicinity of Blace. It is engaged in crop production of corn, wheat, clover, etc. and it is not engaged in livestock. The products are sold in the market. In addition to crop production, it is engaged in production of fruit, plums and cherries. It has all the necessary machinery for cultivation and five family members who are engaged in the production.

There are 11 efficient livestock farms. Holdings 47lp, 50lz, 54lb and 59lk are reference for most holdings. The results have shown that in the observed set, 11 agricultural holdings (41lp, 42lp, 44lp, 46lp, 47lp, 48lz, 49lz, 50lz, 51lb, 54lb, 59lk) were efficient, and the remaining 9 farms (43lp, 45lp, 52lb, 531b, 55lb, 561k, 57lk, 581k, $601 \mathrm{k})$ were inefficient. The results of the surveyed rural holdings with the dominant livestock production from Toplice region show that it has an enviable efficiency score. An example of good practice could be agricultural holdings 461p, 47lp, 49lz, 50lz, $51 \mathrm{lb}, 54 \mathrm{lb}, 591 \mathrm{k}$ which are reference for most holdings. All of these farms have all the machinery necessary for agricultural operation.

Holdings 46lp and 47lp are located in the vicinity of Prokuplje, engaged in livestock production (milk, meat and lambs) and both holdings are at equal distance from the market. On their own property, they produce feed for their farms, and use manure for fertilization of field and fruit crops. There are ten family members working on the farm $461 \mathrm{p}$, and five family members on the 47lp.

Holdings $491 \mathrm{z}$ are $501 \mathrm{z}$, located near Žitoradja, are engaged in livestock production. Farm 49lz produces milk and calves. The entire amount of feed needed for the farm is produced on own land, and in addition peppers are cultivated on $0.5 \mathrm{ha}$, while holding $50 \mathrm{lz}$ is engaged in fattening of beef and produces up to $50 \%$ of the necessary feed on the holding, and the rest is purchased in the market. There are four members of the family working on the first farm, and six on the second.

Farms 511b and 54lb are located in the vicinity of Blace and they are engaged in livestock production, milk and calves. They cooperate with the dairy from Blace, produce feed on their farms and they are also engaged in plum production. Proximity to markets makes them stand out from other farms. There are three family members working on the first farm and four on the second.

The farm 59lk is located in the vicinity of Kuršumlija. It is engaged in livestock production, milk, calves and lambs. This holding is in transition to organic production. Livestock feeds mainly on pasture so the cost of food is generally low, and for the winter period feed is prepared on the farm. There are three family members working on this farm.

The Kruskal-Wallis statistics is used for testing the hypothesis of equality of the average efficiency of the observed primary productions and it was obtained that there was no significant difference in the efficiency of these three groups of individual farms. 


\section{The analysis of projected values}

In the previous paragraphs it is suggested that some farms which are less efficient could become more efficient if they follow the example of similar but more efficient farms. Based on the projected values, which are not shown in the paper due to the large amount of data, models of input elements can be proposed in order for output elements, in this case the value of production, to remain unchanged.

Each holding may have impact on the input elements which we take into consideration and the following conclusions can be made for holdings according to the type of dominant production.

The projected values for farms with dominant fruit production show that 12 of 20 analysed farms are inefficient. Based on the projected values it can be observed that

- the biggest problem is the cost of non-primary production which in inefficient holdings ranges from $52,300 \mathrm{RSD}$ to $533,000 \mathrm{RSD}$, and should be reduced to a range between $31.95 \%$ and $98.71 \%$,

- the land cultivated by these farms should be reduced by $9.84 \%$ to $62.01 \%$,

- the cost of materials and maintenance should be reduced by $9.84 \%$ to $62.03 \%$,

- the service cost should be reduced by $9.21 \%$ to $54.70 \%$,

. in regard to output elements, it is possible to increase the values of non-primary production although, at the same time, the cost of non-primary production is reduced.

In regard to the projected values of the holdings with the dominant crop and vegetable productions, it is noticeable that 13 of 20 analysed farms are inefficient. Based on the projected values it can be observed that

- the land cultivated by these farms should be reduced by $19.35 \%$ to $74.59 \%$.

- the cost of non-primary production in inefficient holdings should be reduced in a range between $32.45 \%$ and $69.83 \%$,

- the cost of materials and maintenance should be reduced by $27.68 \%$ to $64.95 \%$,

- the service cost should be reduced by $19.35 \%$ to $64.95 \%$,

- in regard to output elements, it is possible only in two cases (30cz and $34 \mathrm{cz}$ ) to increase the value of non-primary production and at the same time to reduce the cost of non-primary production.

The projected values of the holdings with the dominant livestock production show that 9 of 20 analysed farms are inefficient. Based on the projected values it can be seen that

- the land cultivated by these farms should be reduced by $1.24 \%$ to $51.89 \%$,

- the cost of non-primary production in inefficient holdings should be reduced in a range between $3.25 \%$ and $51.89 \%$,

- the cost of materials and maintenance should be reduced by $1.24 \%$ to $51.89 \%$, 
- the service cost should be reduced by $7.83 \%$ to $51.89 \%$,

- in regard to output elements, it is possible only in case of $561 \mathrm{k}$ to increase the value of non-primary production and at the same time to reduce the cost of nonprimary production.

\section{Conclusion}

Agro-economic analysis provides the answer to many questions that are crucial for the initiation of agricultural production, as well as its maintenance and improvement. The rational use of all production factors is one of the important conditions of economy in agricultural production. The following analyses are particularly important and necessary: analysis of profitability, cost and cost price analysis, analysis of the market and the prices of agricultural products and analysis of gross margin. Each of these analyses is in a function of productivity, profitability, economic and environmental sustainability as key principles in the modern economy.

In regard to economics and business organization of agricultural holdings, it is necessary to constantly monitor and analyse the experience of the European Union, especially some of the developed countries of the successful economic groupings. This experience shows, shortly, that it is necessary to constantly encourage and support this production (the policy of price) using measures of agricultural policy and other methods. Only in this way, in conjunction of internal efficiency and external support from the state, it is possible to maintain and develop this important and promising production.

Based on the analysis of the farm efficiency with different types of production, it can be concluded that:

Agricultural holdings with dominant fruit production mainly produce cherries and plums, and less apples and pears, mainly on the territory of municipality Blace. Nonprimary production includes the production of corn and wheat, and less livestock production, milk and calves. In the future, they should be more focused on specialty fruit production in order to reduce cost and improve product quality which provides better position in the market.

Agricultural holdings with dominant crop production mainly grow corn and wheat, and less sown grasses and clover, this mainly applies for farms that produce feed for their livestock. Holdings with dominant vegetable production mainly produce tomatoes, peppers and melons. Non-primary production in this case is the production of cherries and plums, and less livestock, production of milk and calves. In the future they should be more focused on production of feed for their own livestock. Such farms are more efficient. In the vegetable production, they should focus on production of vegetables in closed spaces to reduce the cost and improve product quality which provides a better position in the market. Vegetable production is mainly organized on the territory of municipality Žitorađa, so that is a place where it should be expended.

Agricultural holdings with dominant livestock production are mainly engaged in the 
production of milk, calves and lambs, and one of them is engaged in the fattening of beef cattle. As non-dominant productions, mostly on the farms that produce feed for their livestock, corn, wheat, sown grass and clover are grown. Non-primary production in this case is the production of cherries and plums, and less apples and pears. In the future they should be more focused on production of feed for their own livestock. Such farms are more efficient.

- Based on the analysis of 60 holdings it can be concluded that the more efficient farms are those involved in the dominant livestock production, which have their own machines, so the cost of services to them is somewhat lower. Only a small share of feed for livestock is purchased by these on the market, and most of the feed is produced on their own farms.

- For holdings with dominant fruit production, more efficient farms are those engaged in production of cherries. In regard to the input elements of this type of production, the highest cost is occasional labour hired during the harvest season.

- In holdings with dominant field crop production, if it is not accompanied by appropriate livestock production, the land surface should be increased in order to provide more efficient production. In vegetable production, production in closed production facilities is more efficient than production in the open field. Harvest time and a good price can affect the efficiency of these farms.

\section{Literature}

1. Artukoglu, M. M., Olgun, A., Adanacioglu, H. (2010): The efficiency analysis of organic and conventional olive farms: Case of Turkey, Agric. Econ. Czech, vol. 56, no. 2, pp. 89-96.

2. Atici, K. B., Podinovski, V. V. (2015): Using data envelopment analysis for the assessment of technical efficiency of units with different specialisations: An application to agriculture, Omega, vol. 54, pp. 72-83.

3. Baležentis, T., Kriščiukaitienè, I. (2012): Family farm efficiency across farming types in Lithuania and its managerial implications - Data Envelopment Analysis, Journal Management theory and studies for rural business and infrastructure development, Vol. 30, No. 1, pp. 22-30.

4. Banker, R. D., Charnes, A., Cooper, W. W. (1984): Some models for Estimating Technical and Scale Inefficiencies in Data Envelopment Analysis, Management Science, vol. 30, no. 9, pp. 1078-1092.

5. Bojnec, S., Latruffe, L. (2009): Determinants of technical efficiency of Slovenian farms, Post-Communist Economies, Vol. 1, no. 1, pp. 117-124.

6. Bolandnazar, E., Keyhani, A., Omid, M. (2014): Determination of efficient and inefficient greenhouse cucumber producers using Data Envelopment Analysis approach, a case study: Jiroft city in Iran, Journal of Cleaner Production, vol. 79, September 2014, pp. 108115.

7. Charnes, A., Cooper, W. W., Rhodes, E. (1978): Measuring Efficiency of Decision Making Units, European Journal of Operational Research, no. 3, pp. 429-444.

EP 2015 (62) 3 (781-799) 
8. Cooper, W. W., Seiford, M. L., Tone, K. (2007): Data Envelopment Analysis, Springer Science+Business Media, LLC, New York.

9. De Bont, C. J. A. M., van Everdingen, W. H., Koole, B. (2003): Standard gross margins in the Netherlands, The Hague, the Netherlands, LEI, (available at: http://library.wur.nl/ WebQuery/wurpubs/338272).

10. Farrell, M. J. (1957): The measurement of productive efficiency, Journal of the Royal Statistical Society, vol. 120, no. 3, pp. 253-290.

11. Fousekis, P., Spathis, P., Tsimboukas K. (2001): Assessing the Efficiency of Sheep Farming in Mountainous Areas of Greece. A Non Parametric Approach, Agricultural Economics Review, vol. 2, no. 2, pp. 5-15.

12. Galanopoulos, K., Aggelopoulos, S., Kamenidou, I., Mattas, K. (2006): Assessing the effects of managerial and production practices on the efficiency of commercial pig farming, Agricultural Systems, no. 88, pp. 125-141.

13. Haji, J. (2007): Production efficiency of smallholders 'vegetable-dominated mixed farming system in eastern Ethiopia: A non-parametric approach, Journal of African Economies, vol. 16, no. 1, pp. 1-27.

14. Hansson, H., Öhlmér, B. (2008): The effect of operational managerial practices on economic, technical and allocative efficiency at Swedish dairy farms, Livestock Science, vol. 118, no. 1-2, pp. 34-43.

15.Janković, S., Goss, S., Pusić, M., Jovanović, R., Todorović, G.,Tolimir, N., Ivkov, I., Anđelić, B., Dalton, G. (2006): Poslovanje poljoprivrednih gazdinstava u Srbiji 2006, Priručnik, Ministarstvo poljoprivrede šumarstva i vodoprivrede Republike Srbije i institut za primenu nauke u poljoprivredi, Beograd.

16. Krasnić, T. (2008): Model za optimiranje strukture povrtarske proizvodnje, Tampograf, Novi Sad.

17. Manjunatha, A. V., Speelman, S., Chandrakanth, M. G., van Huylenbroeck, G. (2011): Impact of groundwater markets in India on water use efficiency: A data envelopment analysis approach, Journal of Environmental Management, vol. 92, no. 11, pp. 2924-2929.

18. Orović, D. (2014): Survey conducted on individual farms with different types of production in Toplice region, unpublished research questionnaires and results, Faculty of Agriculture, Belgrade, Serbia.

19. Stygar, A., Makulska, J. (2010): Application of mathematical modelling in beef herd management - a review, Ann. Anim. Sci., vol. 10, no. 4, pp. 333-348.

20. Vico, G. (2012): Optimizacija govedarske proizvodnje u Republici Srpskoj na osnovu više kriterijuma, Ph.D. thesis, University in Belgrade, Faculty of Agriculture, Belgrade. 


\title{
OCENA EFIKASNOSTI POSLOVANJA POLJOPRIVREDNIH GAZDINSTAVA SA RAZLIČITIM PROIZVODNJAMA
}

\author{
Dragan Orovićc, Ivana Ljubanović Ralević ${ }^{6}$, Ana Anokić7
}

\begin{abstract}
Sažetak
Predmet ovog rada je korišćenje DEA metodologija za ocenu i analizu ukupne tehničke efikasnost (TE) koja u sebi uključuje čistu tehničku efikasnost (CTE) i skala efikasnost (SE). U radu je analizirano poslovanje tri grupe po 20 individualnih gazdinstava sa različitim primarnim proizvodnjama, ratarskom, voćarskom i stočarskom. Potrebni podaci za izradu osnovnog modela prikupljeni su tako što je sprovedena anketa na 60 poljoprivrednih gazdinstava sa teritorije Topličkog okruga. Anketirana gazdinstva poseduju 92 traktora, 108 raznih plugova, 63 prskalice i drugu potrebnu mehanizaciju. Pored toga obrađuju 677,7 ha poljoprivrednog zemljišta što se nalazi na 1201 parcelu. Ova gazdinstva drže 291 kravu, 118 bikova, 366 svinje, 459 ovce i dr. Sve ovo rade 91 član gazdinstva. Cilj rada je da se utvrdi da li postoji razlika u tehničkoj efikasnosti različitih tipova gazdinstava.
\end{abstract}

Ključne reči: DEA metodologija, tehnička efikasnost, skala efikasnost, porodična gazdinstva, primarna proizvodnja.

5 Mr Dragan Orović, predavač, Visoka poljoprivredno-prehrambena škola strukovnih studija, Ćirila i Metodija 1, 18400 Prokuplje, Srbija, Telefon: +381 273243 11, E-mail: draganorovic@gmail.com

6 Prof. dr Ivana Ljubanović Ralević, redovni profesor, Univerzitet u Beogradu, Poljoprivredni fakultet, Nemanjina 6, 11080 Zemun, Srbija, Telefon: +381 1126153 15, E-mail: iralevic@agrif.bg.ac.rs

7 Asistent Ana Anokić, B.Sc., Univerzitet u Beogradu, Poljoprivredni fakultet, Nemanjina 6, 11080 Zemun, Srbija, Telefon: +381 1126153 15, E-mail: anokicana@agrif.bg.ac.rs

EP 2015 (62) 3 (781-799) 